\title{
Economics
}

\section{Socio-economic Determinants of School Attendance of Punjab, Pakistan}

\author{
Daud Rafique ${ }^{1, \text { * }, \text { Suleman Shaukat }}{ }^{1, \text { * }}$, Sajid Rasul ${ }^{2}$, Zahid Ahmed $^{3}$, Isaac Shahzad ${ }^{2}$, \\ Muhammad Ali Bhatti ${ }^{1}$ \\ ${ }^{1}$ Department of Economics, Forman Christian College, Lahore, Pakistan \\ ${ }^{2}$ Bureau of Statistics, Punjab, Government of Punjab, Lahore, Pakistan \\ ${ }^{3}$ School of Accounting \& Finance, University of Central Punjab, Lahore, Pakistan
}

Email address:

suleman4363@gmail.com (S. Shaukat),daudrafique@gmail.com (D. Rafique)

${ }^{*}$ Corresponding author

\section{To cite this article:}

Daud Rafique, Suleman Shaukat, Sajid Rasul, Zahid Ahmed, Isaac Shahzad, Muhammad Ali Bhatti. Socio-economic Determinants of School Attendance of Punjab, Pakistan. Economics. Vol. 9, No. 1, 2020, pp. 8-16. doi: 10.11648/j.eco.20200901.12

Received: November 27, 2019; Accepted: January 20, 2020; Published: February 18, 2020

\begin{abstract}
Primary education is a key indicator of social and economic development. Since independence 1947, Pakistan has been facing the issue of low attendance rate at primary level. Pakistan has been working with international organizations like UNICEF for many years but unable to achieve the goal of universal primary education. Therefore, the present study focuses on this issue, and investigate the socio-economic determinants of school attendance of primary aged children (5-9 years) at Punjab. For this purpose, the study used MICS (Multiple Indicator Cluster Survey) 2014 as a data set, conducted by Punjab Bureau of Statistics with the selected sample of 31,466 children. The results of descriptive analysis suggest that children in general and girls in particular of Punjab are deprived of their basic right of education. For the regression analysis, Logistic Models are constructed for Punjab. The results of Logistic Model suggest that gender of child, area of residence, wealth quintiles, mother education, father education, gender of household head, age of a child and household size determine the school attendance. As compared to the other factors, the impact of household wealth (wealth quintiles) is found greater in this study. It suggests that large socioeconomic disparities exist in Punjab. Lastly, the study recommends some policies to increase school attendance that can ensure more educational budget for deprived areas in terms of school attendance, and how to utilize its educational budget e.g. incentives to poor households in the form of conditional cash transfers. However, Pakistan must spend standard 4 percent of its GDP on education for the enhancement of human capital in the long run.
\end{abstract}

Keywords: Primary Education, School Attendance, Logistic Regression

\section{Introduction}

Pakistan is one of the signatory country of millennium development goals that ensures universal primary education for primary age children by 2015 . The primary education is for the children aged between 5-9 years in Pakistan. It includes $1^{\text {st }}$ grade to $5^{\text {th }}$ grade of schooling. Unfortunately, due to less effective polices and bad governance in education sector, Pakistan could not succeed to achieve this goal by 2015. According to UNICEF, Pakistan's ranking is $1^{\text {st }}$ in South Asia and $2^{\text {nd }}$ in overall world after Nigeria with 5.1 million out of school children at the age of 5-9 years. It shows an alarming situation in primary education of Pakistan. Therefore, the present study focuses on this issue. Education sector of Pakistan was under the responsibility of Federal Government, Article 25A—Right to education: says that the state is fully responsible to provide free and compulsory education to all children aged between 5 to 16 years (Constitution of Pakistan 1973). However, after 18th amendment, all four provincial governments of Pakistan are responsible for their education sector. Now it is the duty of provincial governments to enforce this law.

Pakistan is located in South Asia. It's estimated population is 207.7 million. Out of this population, 132.18 million and 
75.58 million live in rural and urban areas, respectively [20]. GDP Per Capita Income of Pakistan is US\$ 1560.3 (in terms of current US Dollars) [16]. In case of Punjab, its estimated population was 20.541 million [20]. Whereas in 2017, its estimated population is 110 million and out of these, 40.4 million are urban area residents and 69.6 million are rural area residents [20]. Pakistan has been facing so many issues since its independence 1947, particularly in education sector like low literacy rate, low enrollment rates, high number of out of school children, etc. Low school attendance is an issue which is not only having very high impact on the education sector of Pakistan but also on the economic performance of the country. Thus, it is an issue which must be addressed in order to achieve universal education in Pakistan. Around 18.751 million primary school children are currently enrolled in Pakistan out of which 11.461 million (62 percent) are schooling in public sector and 7.920 million (38 percent) are schooling in private sector (Pakistan Education Statistics 2015-16). UNICEF reports that Pakistan ranking is $2^{\text {nd }}$ in terms of out-of-school children in the world at primary level. Every $10^{\text {th }}$ out-of-school in the world is a Pakistani child [1]. Nearly 33 percent of South Asian children who are out of school live in Pakistan like every third of children [2]. On the basis of these facts, we can say that performance of education in Pakistan is abysmal compared to other developing countries. In case of Punjab, according to MIC final report on Education and literacy rate, net primary attendance ratio of total, males and females is 57.9 percent, 58.9 percent and 56.8 percent, respectively and 41.9 percent are out of school which also highlights the alarming situation.

The primary attendance is important because it is stated in the constitution of Pakistan that every child has a right to education (Article 25A) and it was included in millennium development goals, and is currently a part of sustainable development goal as well as goal no. 4 . Goal no. 4 states that both boys and girls must complete free primary and secondary school by 2030. United Nation Organizations like UNICEF and UNESCO and local organizations in collaboration with Government of Pakistan and it's all provincial Governments are address this issue. In addition to right, the success of a society depends on the basic primary education because each additional year of basic primary schooling raises a person's productivity and decreases its dependence on social resources (W. B report, 1994). The basic aim of education is to make children learn, get to know about their full potential, and live meaningful life in society (Quality Primary Education, UNICEF). It shows that it is a key indicator for social and economic development.

Pakistan has estimated population of 207.7 million, the sixth most populous country in the world. Every $10^{\text {th }}$ world's out-of-school child is a Pakistani child. Low Primary school attendance has very high negative impact on the performance of education sector of Pakistan, and hence on the economic growth of Pakistan. Punjab is population-wise the largest province, almost half of the population of the country is living in it. Punjab contributes 59 percent in the total GDP of Pakistan [22]. It also performs a large share in the development of the country.

The study investigated about children who are at work and having schooling or like to be idle in the context of household wealth and role of ability. The study suggested that parental education was likely to have a positive impact possibly on the perceived returns for the schooling of children with the help of human capital intergenerational transmission. The both parental education effect suggested that more the years of education completion by parents implying more chances for parents to send their children to school full time than to be idle [5]. The findings revealed that the demographic and socioeconomic determinants of school attendance across 63 countries. The multivariate analyses were applied in the series in order to examine how school attendance is affected by child and household background. For this purpose, the study used the household survey data of 63 countries. A logistic model was constructed in the study because school attendance is dichotomous variable in nature. The study investigated both demand-side and supply-side determinants of school attendance of children. the demand side indicators are taken from household surveys of all 63 countries while rest supply-side factors are based school relative factors such as distance to the school, quality of education at school etc. The study concluded that certain children are most probably to be out of school who are belonging to poor families, not having well-educated parents and living in rural area. The school attendance among girls and younger and older children is very low [10]. Both socioeconomic status and education of parents were having significant impacts on school attendance which clearly indicates household wealth, mother's and father's education are key factors in determination of school attendance [12]. Another comparative study shows how school attendance was affected by rural and urban poverty gaps and gender gap in the five sub-Saharan African countries. It suggested that poverty, rural-urban residence and gender bias are primary contributors to disparities. Gender gap existed in the areas where people were deeply concerned about culture and traditions. It also claimed the wealth index as the most important indicator of school attendance [23]. The crosssectional study examined the demand side factors of school attendance of urban children in case of Pakistan. It also analyzed the key factors that can affect boys and girls schooling separately. The findings suggested that household poverty was considered to be an important determinants of child schooling i.e., poor households were more often keeping their children at home during school age due to their unaffordability to the schooling cost. The study perceived that parents of large household preferred to invest less in the schooling of their children because household income may be lower down by higher dependency ratio [3]. There are some factors which affected school choice in rural Punjab. The study used PERI School Choice Survey (2011) which was collected from seven rural districts of Punjab with a sample of 1024 household. It applied a probability choice model as a statistical technique. The key finding suggested that girls schooling is deeply depending on mother education in the 
long run. It also considered as a deprived region where schooling is largely affected by socioeconomic conditions and lack of public services access. The study investigated that parents were 5 percent more likely to send their child to school by increasing the wealth of household. Therefore, Household socioeconomic status was considered to be an important determinant of schooling [4].

There are no detail studies on school attendance of primary education in Punjab. This dataset is the latest available and comprehensive grassroot data on Punjab which covers all 36 districts of Punjab. This analysis helps the study to recommend grassroot level policies depending upon factors which are more effective in Punjab. To achieve SDGs, increasing school attendance and free education, it is a need of the hour to identify causes and determinants of low school attendance in Punjab. By doing this, it can be used as a source of information for future studies as well. Thus, this study was tried to identify the major factors which cause low school attendance.

The economic development of any country highly depends on the education status and skill level of its people. Therefore, the economic performance of any country is highly relying on the human capital in the long run. Thus, the improvement in education system, will also enhance the economic growth in future. The main goal of the study is to explore socioeconomic determinants of school attendance in Punjab and its three regions. By doing this, the study is able to highlights factors which contributes more in determining school attendance. For this purpose, logistic models are constructed to measure the effect of various factors on the school attendance.

\section{Methods}

The cross-sectional study obtains data from MICS (Multiple Indicator Cluster Survey) 2014 which was conducted by Punjab Bureau of Statistic. The data set of MICS Punjab 2014 was designed to provide estimation for many indicators on the household characteristics including socioeconomic indictors for Punjab. This survey was conducted by Bureau of Statistics, Planning and Development, Government of Punjab in collaboration with UNICEF. It was based on three questionnaires i:e questionnaires for household characteristics, women (aged 15-49 years) and children under five years respectively. In this survey, 41,413 households were sampled but only 39,333 were occupied and 38,403 households were successfully interviewed with the response rate of 97.6 percent.

To reduce the recall bias from MICS 2014, the information about the variables school attendance, father and mother education etc. was asked only from children of age (5 to 9) years. Data had some missing-system values which may affected the analysis because the mode of multivariate analysis does not treat missing-systems values. Therefore, data is being cleaned and leveled for the multivariate analysis. Initially the sample size was 31,475 children but due to cleaning, it reduces to 31,466 children. After cleaning of data, a file was made for the sample of children of age (5-9) years including all the variables of households and personal. Due to the absence of data on income or consumption, the survey combined all assets of household for the formation of wealth index (wealth quintiles) by using the technique of principle component analysis. Thus, Wealth index is a proxy variable to income and consumption of household. Note that a data file is generated for all children of age 5-9 years in the year 2014. The study is based on 10 variables in which one is depended, and rest are independent variables.

\section{Theoretical Framework}

The study adopts the household production framework [6]. Under this framework, a household tries to maximize its utility with respect to time, income, cash, production, labor and other constraints. This utility consists of leisure and composite consumption goods of family members. Consumption goods include food expenditures and non-food expenditures as well as schooling of children. In the context of child's schooling, the household production framework explains the decision of the households regarding education of their children. According to it, parents make investment decision, including the investment on the education of children. In this framework, initially the parents maximize the resources of all family members. Then they take decision regarding reallocation of these resources among all members of the household according to their choice (preferences). This educational investment is affected by the future returns of the education because parents expect some future returns on schooling of each child.

In the developing countries, parents prefer boys for schooling than girls because of labor market discrimination against females. Females usually have less wages than males [12]. Parents expect more future returns on sons than daughters because at old age they rely on sons rather than girls. Some studies suggested that gender differential existed in the areas which were deeply cultural rooted [23].

In the poor households, parents are unable to invest in the schooling due to its direct costs, i.e., school fee and transportation costs [11]. Whereas parents in the wealthier households invest more in schooling of children due to excess of funds. It shows that household wealth also has a significant impact on school attendance [25].

In a large household, parents do less investment on the schooling of their children because of low per person (head) income due to higher dependency ratio [13]. The larger household size is negatively associated with school attendance.

Rural-urban disparities also seems to be an important factor in the determination of school attendance. In rural areas, poor households are unable to invest because of extreme poverty and lack of public facilities (lack of school). It is also observed that when household wealth is controlled, children from rural household were more likely to attend school. Hence rural household is affected due to the extreme poverty in rural areas. Whereas urban children are facing the 
problem of child labor due to more job opportunities in the urban areas [23].

The education of both father and mother have a positive impact on school attendance. It is observed that educated parents invest more due to intergenerational effect of education than uneducated parents [5][24].

As far as gender of the head of household is concerned, gender of the head of household plays a significant role on child schooling. The literature suggests that female head of household plays a significant role on school attendance if all financial resources are managed by her. Otherwise male household head matters more [9]. It also suggests that if headship under well-educated mother has a positive impact on child's attendance [17]. In some cases, it has no impact on schooling [15]. Therefore, the mixed results are observed regarding household head [13].

Age of child is also found to be an important determinant of school attendance. It is observed that parents invest more on the older children than younger children [28]. Therefore, it has a positive association with school attendance.

\section{Logistic Regression Model}

In this study the dependent variable is dichotomous in nature, as it is based on this question "Does child aged 5-9 years attend school during current year 2014?" and response is either yes or no. Due to this dichotomous nature of dependent variable, the study applies logistic regression for the empirical analysis. It is suggested that social sciences researchers should use this technique for the analysis of probabilities regarding binary outcomes [21]. The logistic regression analysis is applied in which variables are having categorical outcomes, i.e., success/ failure or Yes or No. The objective of the study is to investigate the socioeconomic factors which have significant impact on school attendance.

The logit model is given below:

$$
\ln \left[\frac{p}{1-p}\right]=\alpha_{0}+\alpha_{1} X_{1}+\alpha_{2} X_{2}+\alpha_{3} X_{3} \ldots . \alpha_{k} X_{k}
$$

$\mathrm{P}=$ Probability to school.

$1-\mathrm{P}=$ Probability not to attend school.

$\mathrm{X}_{1-\mathrm{k}}=$ Explanatory variables

\section{Result and Discussion}

\subsection{Descriptive Statistics Result}

The descriptive statistics shows the overall picture of data set. Table 1 shows the information on the distribution of children aged 5-9 years who attended school during the year 2014. It includes the frequencies and percentages of Children who attend school, Gender, Area of Residence, Mother education, Father education, Wealth quintiles, Household size, Age of child and Gender of household head. It shows that 54.5 percent children aged 5-9 attended school in Punjab. In Punjab, boys and girls are 51.4 percent and 48.9 percent, respectively in the age group of 5-9 years. In Punjab, boys are considerably more than girls in the age group of 5-9 years (51.4 percent and 48.9 percent respectively). Table 1 also shows the considerable difference in the educational level related variables such mother and father educational level. These variables represent categories i.e. none, primary, middle, secondary and higher for educational analysis. These categories may include school dropouts in the way like mother may have just two years of primary schooling. In this study wealth quintile is used in order to consider the resources available to the members of a household. Wealth quintile is divided into five groups from the poorest to the richest. The large gap is found between wealth quantiles. The children belonging to the poorest and the poorer family status are 25.1 percent and 21.4 percent, respectively. Nearly 50 percent of the children belongs to the poorest and poor families compared to only 14.1 percent of richest family status. Table 1 indicates that Punjab is a male dominant province because most of household head (94.2 percent) are males as compared to 5.8 percent females. This shows that all important decisions of families are more likely taken by males in Punjab.

Table 1. Frequency Distribution of School Attendance and Socio-Economic Characteristics of the Respondents.

\begin{tabular}{|c|c|c|c|c|}
\hline \multirow{2}{*}{ Sr. No. } & \multirow{2}{*}{ Variables } & \multirow{2}{*}{ Description } & \multicolumn{2}{|c|}{ Punjab } \\
\hline & & & No. & $\%$ \\
\hline \multirow{3}{*}{1} & \multirow{3}{*}{ Child Attend School } & Yes & 17156 & 54.5 \\
\hline & & No & 14310 & 45.5 \\
\hline & & Total & 31466 & 100 \\
\hline \multirow{3}{*}{2} & \multirow{3}{*}{ Gender } & Boy & 16185 & 51.4 \\
\hline & & Girl & 15281 & 48.6 \\
\hline & & Total & 31466 & 100 \\
\hline \multirow{3}{*}{3} & \multirow{3}{*}{ Area of Residence } & Urban & 10496 & 33.4 \\
\hline & & Rural & 20970 & 66.6 \\
\hline & & Total & 31466 & 100 \\
\hline \multirow{6}{*}{4} & \multirow{6}{*}{ Mother Education } & None & 18062 & 57.4 \\
\hline & & Primary & 5344 & 17.0 \\
\hline & & Middle & 2437 & 7.7 \\
\hline & & Secondary & 3083 & 9.8 \\
\hline & & Higher & 2540 & 8.1 \\
\hline & & Total & 31466 & 100 \\
\hline
\end{tabular}




\begin{tabular}{|c|c|c|c|c|}
\hline \multirow{2}{*}{ Sr. No. } & \multirow{2}{*}{ Variables } & \multirow{2}{*}{ Description } & \multicolumn{2}{|l|}{ Punjab } \\
\hline & & & No. & $\%$ \\
\hline \multirow{7}{*}{5} & \multirow{7}{*}{ Father Education } & None & 9699 & 30.8 \\
\hline & & Primary & 5155 & 16.4 \\
\hline & & Middle & 4242 & 13.5 \\
\hline & & Secondary & 5721 & 18.2 \\
\hline & & Higher & 3687 & 11.7 \\
\hline & & Father not in household & 2962 & 9.4 \\
\hline & & Total & 31466 & 100 \\
\hline \multirow{6}{*}{6} & \multirow{6}{*}{ Wealth Quintiles } & Poorest & 7892 & 25.1 \\
\hline & & Poorer & 6743 & 21.4 \\
\hline & & Middle & 6369 & 20.2 \\
\hline & & Richer & 5801 & 18.4 \\
\hline & & Richest & 4661 & 14.8 \\
\hline & & Total & 31466 & 100 \\
\hline \multirow{4}{*}{7} & \multirow{4}{*}{ Household Size } & Under 5 & 1867 & 5.9 \\
\hline & & $5-9$ & 22440 & 71.3 \\
\hline & & $10 \geq$ & 7159 & 22.8 \\
\hline & & Total & 31466 & 100 \\
\hline \multirow{6}{*}{8} & \multirow{6}{*}{ Age } & 5 & 6032 & 19.3 \\
\hline & & 6 & 6527 & 20.7 \\
\hline & & 7 & 6779 & 21.5 \\
\hline & & 8 & 6675 & 21.2 \\
\hline & & 9 & 5423 & 17.2 \\
\hline & & Total & 31466 & 100 \\
\hline \multirow{3}{*}{9} & \multirow{3}{*}{ Gender of Household Head } & Male & 29636 & 94.2 \\
\hline & & Female & 1830 & 5.8 \\
\hline & & Total & 31466 & 100 \\
\hline
\end{tabular}

According to the results of chi-square analysis of school attendance, it is observed that school attendance is significantly associated with all the variables that are used in this study. The significance of school attendance and other variables are according to the theory. From Table 2, it is seen that school attendance is strongly associated with higher level of mother education, father education, wealth quintiles household size ender of household head, area of residence and gender.

Table 2. Hypothesis testing and chi-square values of independent variables.

\begin{tabular}{|c|c|c|c|}
\hline Hypothesis & Value & Prob & Result \\
\hline Boys are more likely to attend school as compared to girls & 6.971 & 0.009 & Associated \\
\hline Age of child has a positive relationship with school attendance & 6792.189 & 0.000 & Associated \\
\hline Mother education has a positive impact on school attendance of primary age children & 1584.708 & 0.000 & Associated \\
\hline Father education also plays a significant role in determining school attendance & 1531.199 & 00.00 & Associated \\
\hline Wealth of household plays a significant role in determining school attendance & 2787.112 & 0.000 & Associated \\
\hline Children who have female household are more likely to attend school & 13.601 & 0.000 & Associated \\
\hline Household size has a negative impact on school attendance of primary age children & 54.943 & 0.000 & Associated \\
\hline
\end{tabular}

Table 3 shows the characteristics of both boys and girls who are attending school within the reference age group (5-9 years). It shows characteristics of these children based on all key variable of the given study. It shows the total number and percentages of both boys and girls who attended school in overall Punjab according to their area of residence. It highlights the characteristics of school going children according to all key variables. It is observed that boys (55.24 percent) are slightly better than girls (53.76 percent) in terms of school attendance. On the other hand, girls (46.14 percent) are comparatively more out of school in Punjab than boys (44.76 percent). In case of school going children, both boys and girls are mostly living in rural area as compared to urban in Punjab (62.1 percent and 60.8 percent boys and girls, respectively). In case of all key variables like educational variables, most of the mothers are uneducated, and their majority lives in the rural area, i.e., school going children's mother education (61.0 percent and 54.6 percent boys and girls, respectively. 
Table 3. Frequency Distribution of Socio-Economic Gender-wise Characteristics of the Respondents: A Rural-urban Comparison.

\begin{tabular}{|c|c|c|c|c|c|c|c|c|c|}
\hline \multirow{5}{*}{ Variables } & \multirow{5}{*}{ Description } & \multicolumn{8}{|c|}{ Children attending school } \\
\hline & & \multicolumn{4}{|c|}{ Boys } & \multicolumn{4}{|l|}{ Girls } \\
\hline & & \multicolumn{4}{|c|}{$\begin{array}{l}\text { No. }=8941 \\
55.24 \%\end{array}$} & \multicolumn{4}{|c|}{$\begin{array}{l}\text { No. }=8215 \\
53.76 \%\end{array}$} \\
\hline & & \multicolumn{2}{|c|}{ Rural } & \multicolumn{2}{|c|}{ Urban } & \multicolumn{2}{|c|}{ Rural } & \multicolumn{2}{|c|}{ Urban } \\
\hline & & No. & $\%$ & No. & $\%$ & No. & $\%$ & No. & $\%$ \\
\hline \multirow{6}{*}{ Mother Education } & Total & 5549 & 62.1 & 3392 & 37.9 & 4992 & 60.8 & 3223 & 39.2 \\
\hline & None & 3384 & 61.0 & 1074 & 31.7 & 2724 & 54.6 & 977 & 30.3 \\
\hline & Primary & 1013 & 18.3 & 628 & 18.5 & 1067 & 21.4 & 643 & 20.0 \\
\hline & Middle & 435 & 7.8 & 383 & 11.3 & 403 & 8.1 & 397 & 12.3 \\
\hline & Secondary & 472 & 8.5 & 631 & 18.6 & 512 & 10.3 & 575 & 17.8 \\
\hline & Higher & 245 & 4.4 & 676 & 19.9 & 286 & 5.7 & 631 & 19.6 \\
\hline \multirow{5}{*}{ Father Education } & None & 1571 & 28.3 & 576 & 17.0 & 1201 & 24.1 & 508 & 15.8 \\
\hline & Primary & 893 & 16.1 & 491 & 14.5 & 835 & 16.7 & 486 & 15.1 \\
\hline & Middle & 850 & 15.3 & 463 & 13.6 & 761 & 15.2 & 434 & 13.5 \\
\hline & Higher & 524 & 9.4 & 800 & 23.6 & 547 & 11.0 & 739 & 22.9 \\
\hline & Father not in household & 585 & 10.5 & 315 & 9.3 & 565 & 11.3 & 302 & 9.4 \\
\hline \multirow{5}{*}{$\begin{array}{l}\text { Wealth Quintile (wealth } \\
\text { index) }\end{array}$} & Poorest & 1329 & 24.0 & 116 & 3.4 & 936 & 18.8 & 102 & 3.2 \\
\hline & Poorer & 1583 & 28.5 & 267 & 7.9 & 1342 & 26.9 & 273 & 8.5 \\
\hline & Middle & 1404 & 25.3 & 638 & 18.8 & 1376 & 27.6 & 578 & 17.9 \\
\hline & Richer & 903 & 16.3 & 1042 & 30.7 & 941 & 18.9 & 1006 & 31.2 \\
\hline & Richest & 330 & 5.9 & 1329 & 39.2 & 397 & 8.0 & 1264 & 39.2 \\
\hline \multirow{5}{*}{ Age of Child } & 5 & 290 & 5.2 & 187 & 5.5 & 330 & 6.6 & 197 & 6.1 \\
\hline & 6 & 794 & 14.3 & 518 & 15.3 & 780 & 15.6 & 533 & 16.5 \\
\hline & 7 & 1311 & 23.6 & 847 & 25.0 & 1258 & 25.2 & 780 & 24.2 \\
\hline & 8 & 1663 & 30.0 & 947 & 27.9 & 1401 & 28.1 & 881 & 27.3 \\
\hline & 9 & 1491 & 26.9 & 893 & 26.3 & 1223 & 24.5 & 832 & 25.8 \\
\hline \multirow[b]{2}{*}{ Household Size } & Under 5 & 333 & 6.0 & 242 & 7.1 & 279 & 5.6 & 178 & 5.5 \\
\hline & $5-9$ & 3931 & 70.8 & 2492 & 73.5 & 3490 & 69.9 & 2374 & 73.7 \\
\hline Household Head Gender & Female & 337 & 6.1 & 234 & 6.9 & 304 & 6.1 & 199 & 6.2 \\
\hline
\end{tabular}

\subsection{Multiple Logistic Regression Analysis Result}

This section discusses the empirical relationship of school attendance with socioeconomic factors. Two logistics models are constructed for empirical analysis. The results are presented in Table 4 as odds ratio and their p-values. The odd ratios indicate the change in odds of school attendance for a one-unit change in explanatory variable. These odd ratios show expected change in odds of school attendance as compared to the reference category (omitted category). Odd ratios equal to 1 indicates no relationship, odd ratios greater than 1 indicates increase in odds or a positive relationship and odd ratios under 1 indicates negative relation or decrease in the odds. In Table 4, first Model of Punjab includes all explanatory variables whereas, second Model of Punjab excludes wealth quintiles and parental education variable in order to show how the wealth index effect variables. The remaining explanatory variables are gender of child, area of residence, mother education, father education, wealth quintile, gender of household head, age of child and household size.

In case of gender of child, it is expected that boys are more likely to attend school in Punjab. Result of Model (1) is in line with previous literature. Odd ratio of boy is 1.08 . It shows that boy category is having a positive relationship with school attendance as compared to girls. It indicates that probability of boy to attend school is 8 percent more than girl.

As far area of residence is concerned, this variable of residence is divided into two categories i.e., rural and urban. Rural category is taken as reference category. Model (1) shows that odd ratio of urban is 0.91 i.e., below 1 . This result suggests that urban children of Punjab are 9 percent less likely to attend school than their rural counterparts of Punjab. This may be resulted due to the presence of urban slums in Punjab and large population of urban is living in these slums. In urban slums, most people are living in extreme poverty. Due to poverty, children prefer to work in labor force rather than going to school to meet their basic necessities. The existence of urban slums and child labor are affecting school attendance in urban area. The study also found the same results when they included wealth index in the Model. They investigated that rural children in Zimbabwe and Uganda were more likely to attend school as compared to urban children [23]. In the same way, Model (1) suggests that wealth quintile is statistically highly significant and emerges as an important factor of school attendance. The odd ratios of wealth quintiles suggest that the probabilities of school 
attendance increase with the increase in household wealth. For example, odd ratio of poorer category is 2.35 . It indicates that the chances of school attendance are expected to be 2.35 times more if child belongs to poorer household as compared to reference (poorest). The estimated odd of middle class has also positive significance and high magnitude. The odd ratio of wealth quintile (richest) is 3.99. It indicates that chances of school attendance are expected to be 3.99 times more if a child is living in richest quintiles as compared to poorest wealth quintiles. These results are not only statistically highly significant but also are in line with the recent studies [12] and [10].

Model (2) also estimates the odd ratios of overall Punjab but it excludes the impact of wealth quintile and both father and mother education. By doing this, the direction of area residence is changed, and gender of head also become significant. Model (2) includes gender of child, area of residence, age of children, gender of household head and household size as an explanatory variable. The odd ratio of urban area is greater than 1 in Model (2) i.e., 1.87. It suggests that children in urban area are 87 percent more likely to attend school as compared to their rural counterparts. It shows that large rural- urban disparties exist if wealth index is not controlled in the Model. Urban children have easy access to schools compared to rural children. Therefore, they can easily get schooling.

In the study, it is evident that educational variables are statistically significant. In Model (1), odd ratios of mother education are statistically highly significant ( $\mathrm{p}$-value < 0.001). The chances of school attendance of children are higher whose mother have some education as compared to those whose are uneducated mothers. The odd ratio of mothers with higher education creates 2.16 times more chances for their children to attend school as compared to reference category (none education). It is also observed that father education also plays a positive role in determining school attendance. The odd ratio of higher education shows that those fathers who have higher level of education increases 2.09 times more chances for children to attend school as compared to reference category (none education). Finally, odd ratios of father not in the household category is also found significant with the value of 1.64. It means that children do not have father in the household are 64 percent more likely to attend school as compared to reference category.

Model (2) also reports similar results as reported in Model 1. It suggests a positive relationship of child's age with school attendance. It shows that age of 6 years category is significant with the odd ratio of 3.80. It indicates that at age of 6 years, the probability of school attendance increases by 3.80 times as compared to reference ( 5 years children). By observing the results of both Models, it is concluded that children are more likely to attend school after the age of 5 years. Hence, we can say that they start schooling after their official starting age of schooling ( 5 years).

In case of household size, it is expected that larger household size has a negative impact on school attendance due to high dependency ratio. In both Models, it negatively associates with school attendance. In model 2 , the odd ratio of 10 and above members is statistically highly significant with the value of 0.83 . It suggests that children who have household size 10 and above members are 17 percent less likely to attend school as compared to reference category.

In model 1, the gender of household head is found insignificant. Whereas in Model (2), gender of household head is also found significant. It indicates that children who have male household are 13 percent less likely to attend school as compared to reference category. These results indicate that females are good decision maker particularly in case of schooling.

Table 4. Logistic Regression Analysis of School Attendance (MICS 2014): An Empirical Analysis.

\begin{tabular}{|c|c|c|c|c|c|}
\hline \multirow{4}{*}{ Serial No. } & \multirow{4}{*}{ Variables } & \multicolumn{2}{|l|}{ Punjab } & \multicolumn{2}{|l|}{ Punjab } \\
\hline & & Model (1) & & \multirow{2}{*}{\multicolumn{2}{|c|}{$\begin{array}{l}\text { Model (2) } \\
\text { No.= }=31466 \\
\end{array}$}} \\
\hline & & \multicolumn{2}{|l|}{ No. $=31466$} & & \\
\hline & & Odds Ratio & P-value & Odds Ratio & P-value \\
\hline \multirow{3}{*}{1} & Gender & & & & \\
\hline & Girl (Reference) & & & & \\
\hline & Boy & 1.08 & 0.003 & 1.06 & 0.024 \\
\hline \multirow{3}{*}{2} & Area of Residence & & & & \\
\hline & Rural (Reference) & & & & \\
\hline & Urban & 0.91 & 0.013 & 1.87 & 0.000 \\
\hline \multirow{6}{*}{3} & Wealth Quintiles & & & & \\
\hline & Poorest (Reference) & & & & \\
\hline & Poorer & 2.35 & 0.000 & & \\
\hline & Middle & 3.75 & 0.000 & & \\
\hline & Richer & 3.86 & 0.000 & & \\
\hline & Richest & 3.99 & 0.000 & & \\
\hline \multirow{6}{*}{4} & Mother Education & & & & \\
\hline & None (Reference) & & & & \\
\hline & Primary & 1.59 & 0.000 & & \\
\hline & Middle & 1.78 & 0.000 & & \\
\hline & Secondary & 2.16 & 0.000 & & \\
\hline & Higher & 2.16 & 0.000 & & \\
\hline
\end{tabular}




\begin{tabular}{|c|c|c|c|c|c|}
\hline \multirow{4}{*}{ Serial No. } & \multirow{4}{*}{ Variables } & \multicolumn{2}{|l|}{ Punjab } & \multicolumn{2}{|l|}{ Punjab } \\
\hline & & \multicolumn{2}{|l|}{ Model (1) } & \multicolumn{2}{|l|}{ Model (2) } \\
\hline & & No. $=31466$ & & No. $=31466$ & \\
\hline & & Odds Ratio & P-value & Odds Ratio & P-value \\
\hline \multirow{7}{*}{5} & Father Education & & & & \\
\hline & None (Reference) & & & & \\
\hline & Primary & 1.48 & 0.000 & & \\
\hline & Middle & 1.69 & 0.000 & & \\
\hline & Secondary & 1.92 & 0.000 & & \\
\hline & Higher & 2.09 & 0.000 & & \\
\hline & Father not in household & 1.64 & 0.000 & & \\
\hline \multirow{3}{*}{6} & Gender of Household head & & & & \\
\hline & Female (Reference) & & & & \\
\hline & Male & 1.10 & 0.129 & 0.87 & 0.022 \\
\hline \multirow{6}{*}{7} & Age of child & & & & \\
\hline & 5 years (Reference) & & & & \\
\hline & 6 years & 4.54 & 0.000 & 3.80 & 0.000 \\
\hline & 7 years & 14.19 & 0.000 & 9.84 & 0.000 \\
\hline & 8 years & 28.18 & 0.000 & 17.83 & 0.000 \\
\hline & 9 years & 45.58 & 0.000 & 28.25 & 0.000 \\
\hline \multirow{4}{*}{8} & Household size (Members) & & & & \\
\hline & Under 5 (Reference) & & & & \\
\hline & $5-9$ & 0.84 & 0.005 & 0.81 & 0.000 \\
\hline & 10 and above & 0.76 & 0.000 & 0.83 & 0.003 \\
\hline 9 & Constant & 0.02 & 0.000 & 0.11 & 0.000 \\
\hline
\end{tabular}

\section{Conclusion and Policy Recommendation}

\subsection{Conclusion}

This study is conducted to investigate the socioeconomic determinants of school attendance in Punjab. The study concludes that only 54.6 percent children aged 5-9 years are going to school. It shows that nearly 50 percent of children are out-of-school in Punjab. A large gender differential also emerges in Punjab. It also suggests that girls are less likely to attend school as compared to boys within the given age of 59 years. As far as area of residence is concerned, after controlling household wealth, rural children are more likely to attend school as compared to urban children in Punjab. But the second model (without wealth) suggests that urban children have more chances compared to rural children. This indicates that most of children are living in extreme poverty in rural area. Therefore, poverty is a real cause of low attendance instead of residence because it is observed that children from richest quintile are 4-5 times more likely to attend school as compared to children from poorest household in Punjab. It indicates that household wealth has a larger impact on school attendance than other determinants. Parental education also plays a positive role in determining school attendance due to its intergenerational impact on child's schooling in Punjab. Mother education is comparatively more mattering than father education in Punjab which is also supported by the previous studies [14]. The study also finds the results of gender of household head are in line with the previous literature. In Punjab, female household head more matters than male household head. It is also observed that children attend school later than 5-year age (the official year to start schooling). A large household size negatively impacts school attendance in Punjab due to higher dependency ratio. Thus, the study concludes that gender, rural urban residence, wealth quintiles, mother education, father education, gender of household head, age of child and household size have significant impact on school attendance and these are the important socioeconomic determinants of school attendance but household wealth emerges as the most influential factor of school attendance.

\subsection{Policy Recommendation}

Government of Punjab should allocate more budgets for education budget for deprived regions in terms of school attendance. In this way, it may easily target the students who are at risk of being out-of-school especially due to child labor and poverty. With the help of excessive budget, Government may initiate early childhood development program, pro-poor-economics incentives like food-for-education programs and conditional cash transfers to increase school attendance and, reduce poverty and child labor particularly among poor households.

Government should also promote education awareness programs for the parents with the help of mass media campaigns. In this way, it may easily aware the parents about the importance of education and its educational policies. The gender-sensitive policy must also be formulated for the eradication of large gender differential in Punjab that may help to bring more girls to schools. Government should also introduce family planning programs to reduce household size. Last but not the least, there should be a need of a new development policy regarding education sector which ensures Pakistan to spend at least standard 4 percent of GDP on its education sector for the enhancement of human capital in the 
long-term.

\section{References}

[1] Ailaan, A. (2014). 25 million broken promises: the crisis of Pakistan's out-of-school children. Islamabad: AIif Ailaan. Retrieved from https://d3n8a8pro7vhmx.cloudfront.net/alifailaan/pages/475/at tachments/original/1415177621/25_Million_Broken_Promises _Report.pdf?1415177621

[2] Alaan, A. (2014). Pakistan District Education Rankings. Islamabad: Alif Alaan. Retrieved from https://d3n8a8pro7vhmx.cloudfront.net/alifailaan/pages/1157/ attachments/original/1451652605/District_Ranking_Report_B inded_-_comp.compressed.pdf?1451652605

[3] Azid, T., \& Ejaz, R. A. (2010, May). Who Are The Children Going To School in Urban Punjab (Pakistan)? International Joural of Social Economics, 37 (6), 442-465.

[4] Ahmed, H., Amjad, S., Habib, M., \& Shah, S. A. (2013). Determinants of School Choice Evidence From Rural Punjab, Pakistan. Centre for Research in Economics and Business Lahore School of Economics Working Paper No. 01-13.

[5] Bacolod, M. P., \& Ranjan, P. (2008, July). Why Children Work, Attend School, or Stay Idle: The Roles of Ability and Household Wealth. Economic Development And Cultural Change,, 56 (4), 791-828.

[6] Becker, G. S. (1968). Human Capital: A theoretical and Empirical Analysis with special Reference to Education. New York: Columbia University Press.

[7] Becker, G. S. (1981). A Treatise on the Family. London, England: Harvard University Press Combridge. Retrieved from https://brunofvieira.files.wordpress.com/2012/12/garybecker-a-treatise-on-the-family.pdf

[8] Chaudhury, N., Christiaensen, L., \& Asadullah, M. N. (2006). Schools, Household, Risk and Gender: Determinants of Schooling in Ethiopia. CSAE WPS.

[9] Escudera, W. S., \& Marchionni, M. (1999). Household Structure, Gender, and the Economic Determinants Attendance in Argentina. The World Bank.

[10] Hattori, H. (2014). Demographic and socioeconomic determinants of school attendance. UNICEF, 1-14.

[11] Jayachandran, U. (2002, June). Socio-Economic Determinants of School Attendance in India. Centre For Development Economics Working Paper No. 103.

[12] Kazeem, A., Jensen, L., \& Stokes, C. S. (2010, may). School Attendance in Nigeria: understanding the impact and intersection of gender, urban-rural residence, and socioeconomic Sstatus. University of Chicago press journals, 54 (2), 295-319.

[13] Khan, E. A., \& Ali, K. (2003). Determinants of Schooling in Rural Areas of Punjab. The Lahore Joural of Economics, 8 (2), 99-122.
[14] Khan, Jahangir, Muhammad. (2019). School Quality and Parental Schooling Decisions for Their Children: Public and Private Schools in Rural Pakistan. The Pakistan Development Review, 58: 2, 177-202.

[15] Maitra, P., \& Rajan, R. (2002). The Joint Estimation of Child Particiption in Schooling and Employment: Comparative Evidence From Three Continents. Oxford Development Studies, 30 (1), 41-62.

[16] Ministry of Finance, Pakistan. (2015-16). Economic survey of pakistan. Ministry of Finance, Pakistan.

[17] Mahmood, T., Saqib, N. U., \& Qasim, M. A. (2017). Parental Effects on Primary School Enrolment under Different Types of Household Headship: Evidence from Pakistan. The Pakistan Development Review, 56: 3, 249-264.

[18] NEMIS, AEPAM, Ministry of Federal Education and Professional Training, Government of Pakistan (2017, February). Pakistan Education Statistics 2015-2016.

[19] Pakistan Bureau of Statistics Government of Pakistan (1951). Population Census 1951. Retrieved from http://www.pbs.gov.pk/content/population-census.

[20] Pakistan Bureau of Statistics Government of Pakistan (2017). Population Census 2017. Retrieved from http://www.pbs.gov.pk/content/population-census.

[21] Pohlman, J. T., \& Leitner, D. W. (2003, December). A Comparison of Ordinary Least Square and Logistic Regression. The Ohio Journal of Science, 103 (5), 118-125.

[22] Punjab Bureau of Statistic. (2011). Punjab Development Statistic. Lahore: Punjab Bureau of Statistic.

[23] Roby, J. L., Erickson, L., \& Nagaishi, C. (2016, March). Education for Chidren in Sub-Saharan Africa: Predictors implacting School Attendance. Children and Youth Services Review.

[24] Sackey, H. A. (2007). The Determinants of School Attendence and Attainment In Ghana: a Gender Perspective. African Economics Research Consortium (173).

[25] Saasa, K. Sherinah. (2018). Education among Zambian children: linking head of household characteristics to school attendance, Vulnerable Children and Youth Studies, 1-7.

[26] UNICEF. (2005, April). Levels, Trends And Determinants of Primary School Particiption And Gender Parity. UNICEF STRATEGIC INFORMATION Working paper.

[27] UNICEF. (2015). Educate All Girls and Boys in South Asia: The Global Out-of-School Children Intiative. Kathmandu: UNICEF. Retrieved from http://allinschool.org/wpcontent/uploads/2015/04/EducateAllGirlsandBoysUNICEF_ROSA.pdf

[28] Woldehanna, T., Tefera, B., Nicola, J., \& Bayrau, A. (2005). Child Labour, Gender Inequity and Rural/Urban Disparities: How can Ethiopia's National Development Strategries be Revised to Address Negative Spill-over impacts on Child Education and wellbeing? Young Lives Working Paper No. 20. 